\title{
Intensive risk factor control in stroke prevention
}

\section{J. David Spence}

\author{
Address: Stroke Prevention \& Atherosclerosis Research Centre, Robarts Research Institute, Western University, 1400 Western Road, London, \\ ON, N6G 2V2, Canada \\ Email: dspence@robarts.ca \\ Fl000Prime Reports 2013, 5:42 (doi:10.12703/P5-42) \\ This is an open-access article distributed under the terms of the Creative Commons Attribution-Non Commercial License \\ (http://creativecommons.org/licenses/by-nc/3.0/legalcode), which permits unrestricted use, distribution, and reproduction in any medium, \\ provided the original work is properly cited. You may not use this work for commercial purposes. \\ The electronic version of this article is the complete one and can be found at: http://f 1000 .com/prime/reports/m/5/42
}

\begin{abstract}
Stroke prevention is an urgent priority because of the aging of the population and the steep association of age and risk of stroke. Direct costs of stroke are expected to more than double in the US between 2012 and 2030. By getting everything right, patients can reduce the risk of stroke by $80 \%$ or more; however, getting everything right is a tall order. Roughly in order of importance, this requires smoking cessation, maintenance of a healthy weight, a Cretan Mediterranean diet, blood pressure control, lipid-lowering drugs, appropriate use of antiplatelet agents and anticoagulants, and appropriate carotid endarterectomy and stenting. A new approach called "treating arteries instead of targeting risk factors" appears promising but requires validation in randomized trials.
\end{abstract}

\section{Introduction}

With the aging of the population and the steep association of stroke risk with age (Figure 1), the numbers of patients with stroke are expected to increase dramatically. A recent policy statement from the American Heart Association [1] forecasts the following for the US: "Between 2012 and 2030, real $(2010 \$)$ total direct annual stroke-related medical costs are expected to increase from $\$ 71.55$ billion to $\$ 183.13$ billion. Real indirect annual costs (attributable to lost productivity) are projected to rise from $\$ 33.65$ billion to $\$ 56.54$ billion over the same period. Overall, total annual costs of stroke are projected to increase to $\$ 240.67$ billion by 2030 , an increase of $129 \% "$.

Our hospitals and health-care systems will be overwhelmed with stroke patients unless we can prevent this situation. It is therefore crucial for physicians to be able to do an excellent job in stroke prevention - not just a formulaic attempt to prescribe the medications recommended by consensus guidelines, but a thoughtful job of identifying the underlying cause of the impending stroke and achieving control of all the risk factors.

When a patient presents to my urgent transient ischemic attack (TIA) clinic, I say "This is a very important situation, and it is crucial that we get everything right. If we don't do anything, your risk of another stroke in the next three years is around $30 \%$ to $40 \%$, but if we get everything right, we can reduce that risk by $80 \%$ or more. Unfortunately, the two most important things we can do are things you need to do for yourself: quit smoking and learn to follow the Mediterranean diet from Crete. So we need to work together here". It is for that reason that I wrote the book: How to Prevent Your Stroke [2].

Getting everything right is a tall order, but is crucial. Hackam and Spence [3] estimated that the combination of all the available options for stroke prevention would reduce the risk of recurrent stroke by $80 \%$. Table 1 shows the results of that analysis, with stroke prevention strategies ranked in order of importance. In the absence of indications for anticoagulation or endarterectomy, the top two interventions that apply to all patients are diet and smoking cessation. In this review, I will focus on lifestyle change, blood pressure control, lipid-lowering therapy, appropriate use of antiplatelet agents and anticoagulants, appropriate carotid endarterectomy or stenting, and a strategy that I call "treating arteries instead of risk factors". 
Figure I. The steep increase in risk of stroke with age

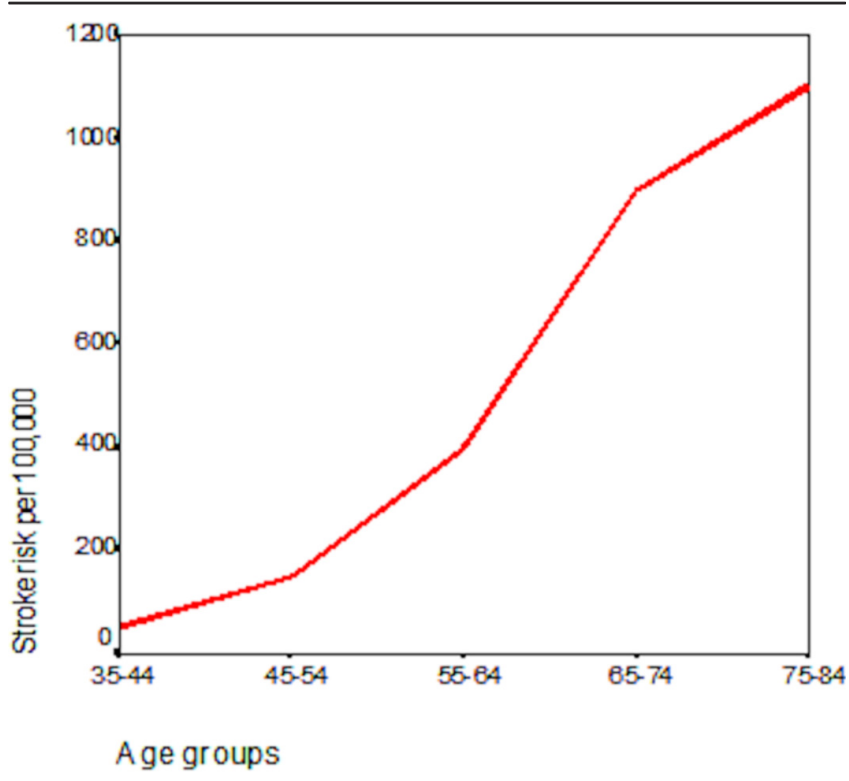

The annual risk of stroke per 100,000 people increases from approximately 35 at age 35 to I,I00 by age 80 . Based on data from [99].

Table I. Rank of stroke prevention strategies in order of importance

\begin{tabular}{lc}
\hline Strategy & Risk reduction \\
\hline Dietary modification & $44 \%$ \\
Smoking cessation & $36 \%$ \\
Exercise & $28 \%$ \\
Aspirin & $22 \%$ \\
Statins & $21 \%$ \\
Antihypertensives & $21 \%$ \\
Glycemic control & $19 \%$ \\
Special cases & \\
Carotid endarterectomy & $48 \%$ \\
Oral anticoagulants & $45 \%$ \\
\hline
\end{tabular}

Based on results of meta-analyses, as reviewed by Hackam and Spence [3] in 2007.

\section{Lifestyle change}

The importance of lifestyle is vastly underestimated by most physicians. In the US Health Professionals study [4], participants who adhered to all five healthy lifestyle choices had an $80 \%$ reduction of ischemic stroke compared to those who adhered to none. The healthy choices were not smoking, maintaining a healthy weight, moderate exercise, modest alcohol consumption, and scoring in the top $40 \%$ of a healthy diet score.

\section{Diet}

Too often, specialist physicians see this as the job of the dietitian, the family doctor, or some other health-care provider. The problem with saying "you need to see a dietician", without any further discussion of the importance of diet, is that the message received is "the doctor doesn't think this is very important". It is important for the physician to at least begin the conversation about diet, emphasizing its importance. In my clinic, I give out a booklet summarizing dietary recommendations, with recipes taken from my book for the public [2]. I recently reviewed nutrition in stroke prevention [5].

\section{Weight control}

The arithmetic of weight control is simple: to lose a pound, the patient must either burn up or forego eating 3,500 calories. Walking a mile only burns 100 calories, so to lose a pound a patient either needs to walk 35 miles or cut out 500 calories a day for a week. To lose 50 pounds would require walking 1,750 miles or cutting out 500 calories a day for a year. This means that it is much easier to lose weight by reducing calorie intake than by exercising; of course, a combination of exercise and calorie restriction is better because exercise improves insulin resistance. Patients need to know the calorie values of the foods they consume and to avoid foods that are very high in calories - they need to eat more lowcalorie food and less high-calorie food. The Mediterranean diet, described below, is helpful in this regard. This is illustrated in Figure 2. Some patients may require bariatric surgery, which can be lifesaving for morbidly obese people.

\section{Mediterranean diet}

Ancel Keys, the leader of the Seven Countries Study, described the Cretan Mediterranean diet as follows: "The heart of this diet is mainly vegetarian, and differs from American and northern European diets in that it is much lower in meat and dairy products and uses fruit for dessert" [6]. In the Lyon Diet Heart study [7], this diet reduced strokes and coronary events by more than $60 \%$ in 4 years compared to a "prudent Western diet", amounting to the National Cholesterol Education Program step 1 diet. I suspect the results were disbelieved because they seemed too good to be true and because they were achieved without a reduction in fasting levels of low-density lipoprotein (LDL) cholesterol [8]. However, diet is not about fasting cholesterol levels; it is about the post-prandial state, and dietary cholesterol is harmful, even though it does not much increase fasting LDL levels. For about 4 hours after a high-cholesterol meal, there is increased oxidative stress, vascular inflammation, impaired endothelial function, and nearly a $40 \%$ increase in oxidation of LDL cholesterol [9]. The benefit of the Mediterranean diet was recently confirmed in a primary prevention study in Spain [10]. In that study, in a high-risk primary prevention setting, a Mediterranean diet reduced the risk of major 
Figure 2. The calorie clock

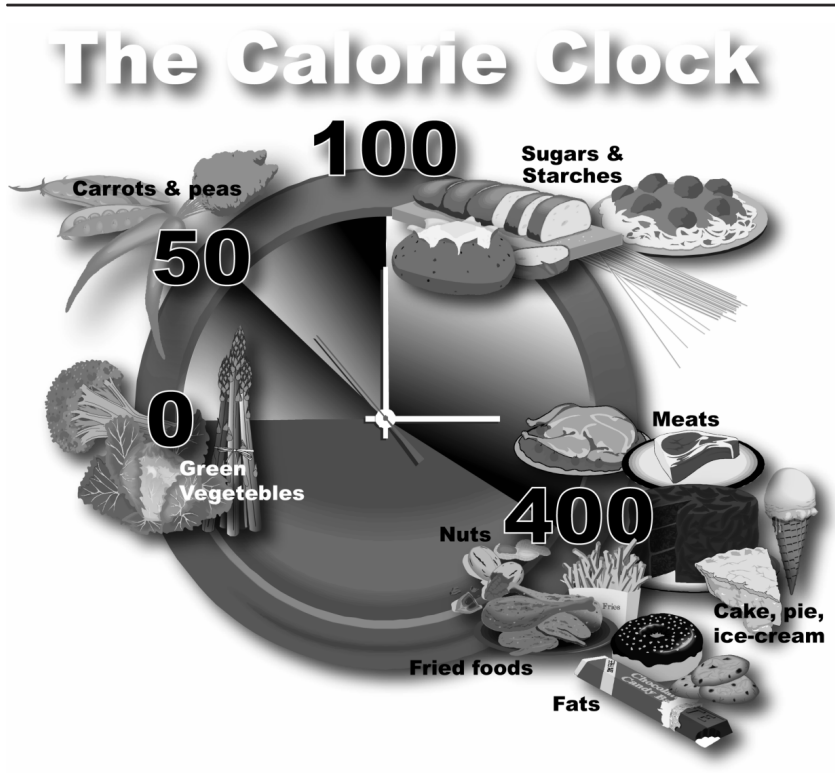

Patients who need to lose weight should eat more fruits and vegetables and whole grains and less fat-containing food such as meat, cake, pie, and ice cream. A large store-bought muffin contains about 450 calories; a small low-fat muffin contains 200 . There are 10 calories in a single potato chip, 7 in a peanut, and 15 in a cashew. Green leaves have virtually no calories, because we cannot digest cellulose. Fat contains nearly twice as many calories per gram as protein or carbohydrates - about 25 calories in a teaspoon of sugar, and nearly 50 in a teaspoon of fat - even good, healthy olive oil. Reproduced with permission from Vanderbilt University Press [2].

cardiovascular events (stroke, myocardial infarction, or death from cardiovascular cause) by $30 \%$. It is possible that similar benefits might be obtained by following a vegetarian diet. A British study showed a 32\% lower risk among vegetarians compared with a usual (unhealthy) diet; a study in Seventh Day Adventists [11] showed that a vegetarian diet reduced ischemic heart disease by $19 \%$ and cardiovascular disease by 13\%. A key issue, particularly with the epidemic of obesity and diabetes, is that the Israeli diet study [12] comparing a lowcarbohydrate versus a low-fat versus a Mediterranean diet showed very convincingly that the Mediterranean was the best for diabetes and insulin resistance. In that study, which achieved excellent adherence over the course of 2 years, weight loss was virtually identical on the Mediterranean diet and the low-carbohydrate diet and was significantly better on both than with the low-fat diet. Furthermore, in my experience, the Mediterranean diet is a much easier change for most North American patients, and there have been no head-to-head comparisons of a Cretan Mediterranean diet versus a vegetarian or vegan diet. For all these reasons, I recommend the Mediterranean diet for stroke prevention.
Egg yolks increase carotid plaque burden by approximately 60\%, as much as smoking does $[13,14]$. Part of the reason is probably the very high cholesterol content: a single large ( $65 \mathrm{~g}$ ) egg yolk contains $237 \mathrm{mg}$, more than the $210 \mathrm{mg}$ in a Hardee's Monster Thickburger (which contains 12 ounces of beef, three slices of cheese, and four slices of bacon) and more than the recommended limit of dietary cholesterol of less than $200 \mathrm{mg} /$ day. Obviously, the burger, with a high content of saturated fat, is worse than the egg yolk. However, the recommended daily intake of cholesterol for patients at risk of vascular disease is less than $200 \mathrm{mg} /$ day $[15,16]$. Consequently, the egg yolk, with its $237 \mathrm{mg}$ of cholesterol and $250 \mathrm{mg}$ of lecithin, should be avoided by patients at risk of vascular disease. It turns out, however, that it is not only the cholesterol in egg yolk that is harmful. Hazen's group showed, first in an animal model [17] and then in patients referred for coronary angiography [18], that phosphatidylcholine (lecithin) is converted by the intestinal flora to trimethylamine. Trimethylamine is oxidized in the liver to trimethylamine n-oxide (TMAO), which caused atherosclerosis in their mouse model [19], and markedly increased the risk of major cardiovascular events in patients referred for coronary angiography [18]. Egg yolk consumption increases the risk of diabetes [20] and, in diabetics, markedly increases cardiovascular risk [21].

Taking all this into account, the best diet for stroke prevention, and the best diet for diabetics and prediabetics [12], is the Cretan Mediterranean diet. This is a diet that is high in beneficial oils (olive and canola), whole grains, fruits, vegetables, lentils, beans, and nuts and much lower in cholesterol and animal flesh than most North Americans are used to. The intake of animal flesh should be kept to approximately 2 ounces per day or 4 ounces every other day, and egg yolks should be avoided. I encourage patients to make a nice tasty omelet or frittata with egg whites or, what I think is more enjoyable, egg substitutes such as Better'n Eggs, Egg Beaters or Egg Creations.

\section{Smoking cessation}

The threat posed by a recent TIA or stroke presents a special "teachable moment" for smokers who may not previously have been ready to quit. Burt et al. [22] showed that, in the setting of recent myocardial infarction, $70 \%$ of smokers could be persuaded to quit. I use a parable borrowed from a Lancet article on weight loss [23]: "Yes, quitting smoking is very difficult. It doesn't matter; it has to be done. If you are walking along the lakeshore and one of your grandchildren is drowning, it doesn't take will power to go into the lake; it just has to be done. Smoking increases your risk of stroke six-fold, and 
quitting smoking is the most important thing you can do to reduce your risk, so it just has to happen" [2].

It is crucial to show the patient that you understand how difficult it is to quit, that you are on the patient's side, and that there are things you can offer that will help. Many patients (and many physicians) are under the impression that nicotine replacement is hazardous; however, continuing to smoke is much more hazardous. Patients need permission to use as much nicotine replacement as it takes. A $21 \mathrm{mg}$ nicotine patch delivers about as much nicotine as smoking half a pack of cigarettes a day, so some patients may need two patches at first, and in addition they can use nicotine gum, nicotine spray, or nicotine inhaler (or a combination of these) in as large a quantity as it takes to deal with the addiction.

Medications such as bupropion and varenicline are helpful in combination with nicotine replacement. Varenicline is probably more effective than bupropion, but the latter might be more appropriate for patients with a history of depression. Counseling will improve quit rates; many hospitals have implemented the Ottawa Model [24]. The excellent chapter by Pipe in my recent book with Henry Barnett [25] is a helpful reference on smoking cessation.

\section{Blood pressure control}

Despite fairly strenuous efforts of national bodies dedicated to blood pressure control, many patients with hypertension - about half - remain uncontrolled [26]. Among patients receiving treatment for hypertension, $90 \%$ of strokes occur in patients with resistant hypertension [27]. Hypertension contributes to atherosclerosis, but with regard to stroke, the main effect of high blood pressure per se is that it directly causes strokes due to small vessel disease. Hyaline degeneration and fibrinoid necrosis cause lacunar infarction when arterioles occlude and cause intracerebral hemorrhage when they rupture. These events occur at the base of the brain, in a territory that Hachinski $[28,29]$ called the vascular centrencephalon, which is the ancient part of the brain where short straight arteries with few branches transmit high pressure straight through to the resistance vessel. The cortex is supplied by long arteries with many branches, like a step-down transformer. This is why lacunar infarctions and intracerebral hemorrhages occur in the basal ganglia, internal capsule, brainstem, and cerebellum [30]. Controlling hypertension virtually eliminates these strokes but has little effect on strokes due to large artery disease, as we found through an experiment of nature in London, Ontario [31].

There are three main causes of resistant hypertension: non-compliance, consumption of substances that aggravate hypertension (such as sodium, licorice, decongestants, non-steroidal anti-inflammatory drugs, and alcohol in excess), and secondary hypertension. The only non-steroidal anti-inflammatory drug that does not raise blood pressure is sulindac [32].

A major preventable cause of stroke is undiagnosed causes of low-renin hypertension due to salt and water retention. This is a particular problem for AfricanAmericans. Howard et al. [33] found that black patients were less likely to have their blood pressure controlled despite a higher rate of diagnosis, higher rates of treatment, and more intensive therapy.

I have suggested that appropriate attention to this issue could virtually eliminate the nearly twofold excess of stroke in black patients [34]. Although it is well known that black patients are more likely to have low and suppressed levels of plasma renin activity and are more likely to retain salt and water [35], there is insufficient attention to the reasons for this phenomenon. Primary aldosteronism accounts for approximately $20 \%$ of resistant hypertension [36], which is increasingly being recognized as familial and largely due to bilateral adrenocortical hyperplasia [37], and therefore is primarily treated medically [38]. The preferred therapy is aldosterone antagonists, not only for reasons of blood pressure control but because aldosterone directly harms the arteries and the heart [39].

Black people are more likely to have adrenocortical hyperplasia [40] and primary aldosteronism [41,42]. Variants of Liddle's syndrome, a renal tubular sodium channel mutation that causes salt and water retention, accounted for $5 \%$ of hypertension in black people in the UK [43], 6\% of hypertension in black people in South Africa (and 20\% of the Khoi San people of the Kalahari) [44], and $6 \%$ of patients attending a Veterans Administration clinic in Louisiana [45]. The specific therapy for Liddle's variants is amiloride. For all these reasons, the algorithm shown in Table 2 is extremely helpful in bringing resistant hypertension under control, particularly in black patients.

\section{Lipid-lowering therapy}

The benefit of lipid-lowering drugs in stroke prevention is much underestimated by consideration of only the $16 \%$ reduction of stroke in the intention-to-treat analysis of the Stroke Prevention by Aggressive Reduction in Cholesterol Levels (SPARCL) trial [46]. That analysis included all stroke subtypes, many of which were lacunar, and many patients randomized to placebo crossed over to statin therapy. Among patients in that study with carotid stenosis, strokes were reduced by 
Table 2. Physiologically individualized therapy for resistant hypertension

\begin{tabular}{|c|c|c|c|}
\hline $\begin{array}{l}\text { Physiologic } \\
\text { driver }\end{array}$ & $\begin{array}{l}\text { Primary } \\
\text { aldosteronism }\end{array}$ & $\begin{array}{l}\text { Liddle's } \\
\text { variants }\end{array}$ & $\begin{array}{l}\text { Renal } \\
\text { renovascular }\end{array}$ \\
\hline $\begin{array}{l}\text { Renin } \\
\text { Aldosterone } \\
\text { Primary } \\
\text { therapy }\end{array}$ & $\begin{array}{l}\text { Low } \\
\text { High } \\
\text { Aldosterone } \\
\text { antagonists } \\
\text { (spironolactone, } \\
\text { eplerenone) or } \\
\text { amiloride where } \\
\text { not available } \\
\text { Rarely surgical }\end{array}$ & $\begin{array}{l}\text { Low } \\
\text { Low } \\
\text { Amiloride is the } \\
\text { specific therapy }\end{array}$ & $\begin{array}{l}\text { High } \\
\text { High } \\
\text { Angiotensin } \\
\text { receptor antago- } \\
\text { nists, renin } \\
\text { inhibitors }^{\mathrm{a}}\end{array}$ \\
\hline
\end{tabular}

After rare causes such as pheochromocytoma, coarctation of the aorta, and licorice consumption are eliminated, most causes of hypertension, and their appropriate therapy, can be identified by measuring plasma renin activity and aldosterone, in a stimulated condition [100], and interpreting them correctly in light of the medications being taken at the time of the measurement [101,102].

${ }^{a}$ Angiotensin-converting enzyme inhibitors are less effective at blocking secondary hyperaldosteronism, because of escape pathways for formation of angiotensin II; a major part of their mechanism of action is blocking the breakdown of bradykinin, with resultant increases in nitric oxide. In a way, they can be thought of as similar to long-acting nitrates.

around 33\%, major coronary events by $43 \%$, and carotid revascularization by 56\% [47]. As discussed below, more intensive therapy, often including ezetimibe, reduced stroke and myocardial infarction by an even higher proportion in patients with asymptomatic carotid stenosis, followed in a prospective cohort study [48].

Whereas a young patient with normal carotid arteries and a stroke due to paradoxical embolism or hypertensive small vessel disease might not benefit much from statins, virtually all older patients with stroke should be treated with statins, in addition to the Mediterranean diet. Statins should not be regarded as a substitute for diet.

There are important issues of persistence with statin therapy. After 3 years, fewer than half of patients prescribed statins are still taking them. In many cases, this is because of symptoms or concerns wrongly attributed to statins by either the patient or the physician. Statins probably do not cause hepatotoxicity [49,50], renal impairment [51], cognitive decline [52], or intracerebral hemorrhage [53]. The causally related adverse effects - myalgia/myopathy and aggravation of diabetes - are probably due to mitochondrial dysfunction [54] caused by depletion of ubiquinone (coenzyme Q10 or CoQ10) among patients genetically predisposed by disorders of mitochondrial function $[55,56]$. CoQ10 is synthesized from one of the intermediary metabolites in the pathway from mevalonic acid to cholesterol [57] and thus depletion of CoQ10 is due to inhibition of HMG CoA reductase. Sufficiently high doses of CoQ10 (and perhaps L-carnitine) can often help patients stay on at least a low dose of statin, and adding ezetimibe can make up for the low dose.

There are also important issues of avoidable drug interactions with statins. Simvastatin and lovastatin, because they are 95\% metabolized in the intestinal wall by CYP3A4, are susceptible to huge interactions, with 20-fold or greater increases in blood levels [58-61], not only with grapefruit but with many drugs, so these two statins should be avoided. A case of rhabdomyolysis 4 days after a woman began eating one grapefruit daily [62] makes it clear that, contrary to some invalid statements in the literature and in pharmaceutical advertising, large quantities of grapefruit are not required for this effect. A single glass of regular grapefruit juice has an effect similar to that of higher doses of grapefruit [60]. Atorvastatin levels are only doubled by this mechanism [63], and rosuvastatin and pravastatin are not affected.

\section{Appropriate use of antiplatelet agents and anticoagulants}

The commonest mistake I see in the management of patients with threatened stroke is a misplaced focus on the dose of aspirin or the choice of antiplatelet agent. Antiplatelet agents are important, but they only reduce the risk of stroke by approximately $25 \%$ and probably only prevent strokes due to embolization of white thrombus (Figure 3). Low-dose aspirin is more effective than high-dose aspirin [64], probably because only a very low dose of aspirin is needed to permanently inactivate thromboxane in circulating platelets (they cannot recover, because they have no nucleus), but higher doses of aspirin prolong the inhibition of endothelial prostacyclin. Clopidogrel alone is only marginally better than aspirin (it reduced stroke by only $1.7 \%$ more than did aspirin in the Clopidogrel versus Aspirin in Patients at Risk of Ischemic Events [CAPRIE] trial [65]), and combined aspirin/dipyridamole is no better than clopidogrel [66]. However, the combination of aspirin and clopidogrel appears to be making a comeback; it is better than either is alone for coronary disease, and combined aspirin and clopidogrel is better than aspirin alone for patients with intracranial stenosis [67] and for patients with transcranial Doppler microemboli [68]. Recent evidence indicates that the combination of clopidogrel and aspirin is more efficacious for secondary stroke prevention than aspirin alone, with a reduction of stroke by 32\% and no increase in major hemorrhage [69]. New antiplatelet agents that are soon to be available may improve on existing agents but are still unlikely to prevent more than a quarter of strokes. 
Figure 3. White thrombus

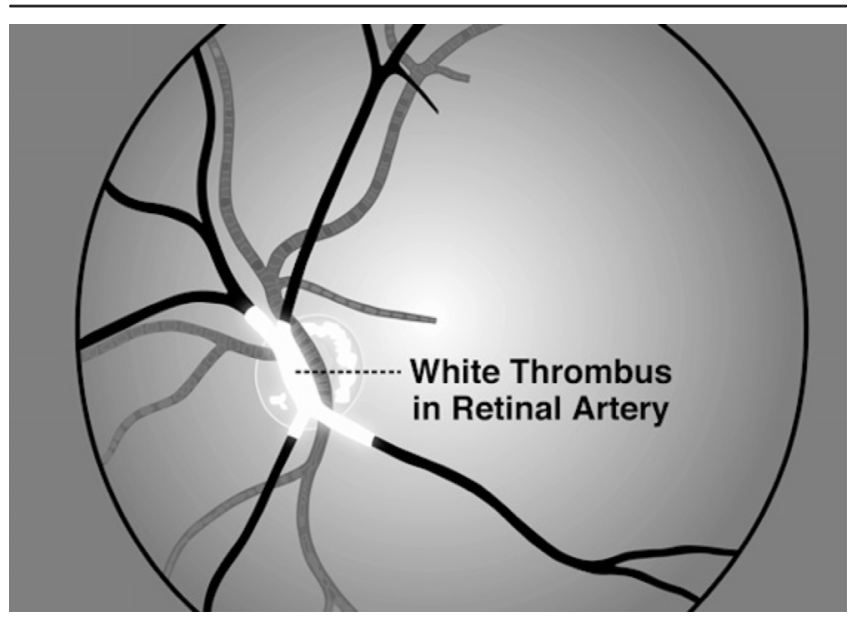

White thrombus, consisting of platelet aggregates, is the target of antiplatelet therapy. I have been present on two occasions when patients had episodes of amaurosis fugax and so was able to observe by ophthalmoscopy the white thrombus oozing through the retinal arteries. As the white thrombus clears, the vision returns, sometimes in vertical or horizontal hemispheres, or in quadrants, as blood flow is restored to each main branch of the retinal artery. To the best of my knowledge, this phenomenon was first described by C. Miller Fisher; a patient who had amaurosis fugax was observed by many participants in Grand Rounds, taking turns with the ophthalmoscope. Reproduced with permission from Vanderbilt University Press [2]

Patients at risk of cardioembolic stroke should be anticoagulated (if at all possible) because antiplatelet agents are not anticoagulants. This issue is increasingly important because, with better control of blood pressure and more intensive statin therapy, strokes due to smallvessel disease and large artery disease have declined in the past 10 years, and consequently the proportion of cardioembolic strokes has doubled to $40 \%$ to $50 \%$ of causes of ischemic stroke [70]. Red thrombus that forms in the setting of stasis in the atrial appendage of a fibrillating left atrium, in a ventricular aneurysm or dyskinetic ventricular segment, or in a deep vein, with a potential to embolize via a right-to-left passage such as a patent foramen ovale, requires anticoagulants [71].

In atrial fibrillation, anticoagulation is three times as effective as aspirin [72]. Dual-antiplatelet therapy adds very little: the addition of clopidogrel to aspirin reduced stroke by only $0.67 \%$ [73], giving a number needed to treat of 149 !

Under-anticoagulation of patients with atrial fibrillation is a huge issue $[74,75]$. Physicians tend to overestimate the risk of falls in older patients and do not recognize that these patients benefit even more from anticoagulation than do younger patients [72]. Physicians also tend to overestimate the risk of bleeding, particularly with the new oral anticoagulants (NOAs). The highest risk of major bleeding with warfarin in real-world practice is in the first 30 days of therapy and is much higher than with NOAs in the clinical trials. NOAs actually do not increase the risk of major bleeding compared to antiplatelet agents, and have a much lower risk of intracerebral hemorrhage than does warfarin.

It is probably impossible to use warfarin well; even in carefully controlled clinical trials, patients spend only about $60 \%$ of the time in the target range of international normalized ratio (INR). Reasons for this difficulty include genetic variants affecting both warfarin metabolism and its pharmacodynamic effect [76], drug interactions, effects of dietary variation, and changes in intestinal flora that produce vitamin K [77]. Fortunately, several NOAs that are at least as efficacious as warfarin, and substantially safer, are now available. High cost, renal excretion (limiting use in patients with renal failure), and concerns about irreversibility of the anticoagulation are some of the reasons why these agents have not yet replaced warfarin entirely. New ones are on the way, as are antidotes to stop bleeding.

The attributable risk of stroke from atrial fibrillation rises steeply with age: from $1.5 \%$ at age 50 to nearly $25 \%$ at age 80 [78]. The true risk in the elderly is probably even higher, as atrial fibrillation is often missed by routine Holter recordings. The Event Monitor Belt for Recording Atrial Fibrillation After a Cerebral Ischemic Event (EMBRACE) study [79] showed that, among patients with cryptogenic stroke and a negative baseline Holter recording, a repeat 24-hour Holter only showed atrial fibrillation in $3 \%$ of patients, whereas a month-long recording detected atrial fibrillation in $16 \%$.

Besides requiring anticoagulants, patients with cardioembolic stroke may require vitamin $\mathrm{B}_{12}$. Metabolic $\mathrm{B}_{12}$ deficiency also increases steeply with age and is not recognized, because the serum $\mathrm{B}_{12}$ level may be in the "normal" range; measurement of methylmalonic acid or total homocysteine is required to confirm the adequacy of $B_{12}$ in patients with low-normal serum $B_{12}$ levels (in Europe, measurement of holotranscobalamin is an option but this is rarely available in North America). In patients attending a stroke prevention clinic, $B_{12}$ deficiency was present in $12 \%$ of those aged less than $50,13 \%$ of those aged 50 to 71 , and $30 \%$ above age 71 . Now that the US and Canada have folic acid fortification of the grain supply, $B_{12}$ is the main dietary determinant of elevated plasma total homocysteine (tHcy), a clotting factor that quadruples the risk of stroke in atrial 
fibrillation [80]. In patients attending my stroke prevention clinic, the proportion with elevated tHcy rises from approximately $20 \%$ at age 40 to $40 \%$ at the age of 80 or over [81].

Contrary to popular belief (resulting from overly simplistic interpretation of clinical trial results), vitamin therapy to lower homocysteine does reduce the risk of stroke $[82,83]$. In older patients with atrial fibrillation, elevated tHcy due to $B_{12}$ deficiency is an important treatable cause of increased thrombosis and elevated risk of stroke.

\section{Appropriate carotid endarterectomy or stenting} Carotid endarterectomy is clearly beneficial for symptomatic carotid stenosis [84] and should be performed soon after the TIA or minor stroke to provide the greatest advantage [85]. Carotid stenting may be indicated for some cases of symptomatic carotid stenosis - patients presenting difficulties for surgery such as a high bifurcation, previous surgery in the region with excess scarring, previous irradiation, and patients at high risk for surgery because of conditions such as pulmonary or cardiac disease. However, compared with endarterectomy, stenting carries twice the risk of stroke; so for most patients, endarterectomy is preferable [86]. Although the risk of symptomatic stenosis on medical therapy will have declined with modern medical therapy, it is still probable that endarterectomy will benefit patients with symptomatic carotid stenosis. Based on the North American Symptomatic Carotid Endarterectomy Trial (NASCET), the number needed to treat to prevent one stroke in 2 years was only 6 for younger patients and only 3 for patients over age 75; in contrast, the number needed to treat to prevent asymptomatic stenosis in 2 years was 86 [87]. Most patients with asymptomatic carotid stenosis will not benefit from endarterectomy or stenting, because with intensive medical therapy the annual risk of stroke or death with medical therapy is now approximately $0.5 \%$, which is well below the risk of surgery or stenting $[48,88,89]$. In the Carotid Revascularization Endarterectomy versus Stenting Trial (CREST) [90], the procedural (30-day) risk of stroke or death for asymptomatic patients was $2.5 \%$ for stenting and $1.4 \%$ for endarterectomy; the 4-year risk was $4.5 \%$ with stenting and $2.7 \%$ with endarterectomy. In the real world, risks are much higher. The 2011 report of Wang et al. [91] documents 1-year risks of stroke or death of $16.7 \%$ for stenting and $11 \%$ for endarterectomy in Medicare patients.

Routine stenting of patients with asymptomatic carotid stenosis, all too often for reasons that do not bear scrutiny [92], is therefore to be deplored $[86,93]$.
Unfortunately, in the United States, there is a national disgrace: as many as $95 \%$ of carotid interventions are for asymptomatic stenosis [91]. A problem unique to the US is the widespread application of carotid stenting by cardiologists, who have no legitimate role in the treatment of this condition. I suspect that part of the problem is the failure of cardiologists to appreciate the effectiveness of the Circle of Willis. Carotid endarterectomy is not about increasing blood flow to the brain; it is about preventing emboli [94]. It is to be hoped that the CREST-2 trial, recently funded, may help put an end to this situation.

The small proportion of patients with asymptomatic stenosis who can benefit from endarterectomy (around $10 \%$ ) can be identified by the presence of microemboli on transcranial Doppler $[95,96]$, by the presence of three or more carotid ulcers on three-dimensional ultrasound, and perhaps by intraplaque hemorrhage on magnetic resonance imaging or by plaque inflammation on positron emission tomography/computed tomography. Although the studies showing that microemboli were associated with markedly higher risk among asymptomatic patients included some patients with a remote history of TIA, the NASCET study showed that among patients randomized to medical therapy, the risk declined rapidly to that of patients randomized to surgery [84]. With modern medical therapy, a remote history of TIA (beyond 18 months in the past) can reasonably be regarded as equivalent to asymptomatic stenosis. In future, we should have several ways to appropriately identify the very small fraction of asymptomatic patients who can benefit from intervention. However, it is clear that they all require intensive medical therapy and that intensive medical therapy is very effective.

\section{Treating arteries instead of risk factors}

A new strategy, "treating arteries instead of targeting risk factors" [97], may improve stroke prevention once it is justified by randomized trials. This approach was based on the recognition that treating patients according to consensus guidelines was failing half of them: half the patients in a study of carotid plaque burden had progression despite treatment, and those with progression of plaque had twice the risk after adjusting for coronary risk factors [98]. Intensive treatment of patients with a high plaque burden, and more intensive treatment of those with progression, reversed the proportions with progression/regression from 50:25 to 25:50 [97] and markedly reduced the risk of patients with asymptomatic carotid stenosis. The 2-year risk of stroke dropped from $8.8 \%$ to $1 \%$, and the 2-year risk of myocardial infarction from $7.6 \%$ to $1 \%$ [48]. 


\section{Conclusions}

Intensive medical therapy is extremely effective and will be required to stave off the impending tsunami of stroke. Smoking cessation, a Mediterranean diet, blood pressure control individualized to the cause of the hypertension, appropriate use of antiplatelet agents and anticoagulants, and appropriate endarterectomy are all important. Our patients deserve no less.

\section{Abbreviations}

CoQ10, coenzyme Q10; CREST, Carotid Revascularization Endarterectomy versus Stenting Trial; LDL, low-density lipoprotein; NASCET, North American Symptomatic Carotid Endarterectomy Trial; NOA, new oral anticoagulant; tHcy, total homocysteine; TIA, transient ischemic attack.

\section{Disclosures}

Grants were provided by the Canadian Institutes for Heath Research, Heart \& Stroke Foundation, and the National Institute of Health/National Institute of Neurological Disorders and Stroke. Lecture honoraria/travel support/consulting fees were provided by Sanofi Bayer Merck and Boehringer-Ingelheim Research support for investigator-initiated projects was provided by Pfizer Inc. (substantial donation in kind of medication to support HSF grant for clinical trial) and Merck (small funds to support a summer research student). Contract research was conducted with all of the above pharma/device companies and Takeda Pharmaceutical Company Limited, Bristol-Myers Squibb Company, Servier Wyeth Miles Roussel-Uclaf NMT AGA Gore. David Spence is a Shareholder and officer of Vascularis.com.

\section{References}

I. Ovbiagele B, Goldstein LB, Higashida RT, Howard VJ, Johnston SC, Khavjou OA, et al.: Forecasting the Future of Stroke in the United States: A Policy Statement From the American Heart Association and American Stroke Association. Stroke 2013.

\section{FlOOOPrime}

RECOMMENDED

2. Spence JD: How to prevent your stroke. Nashville: Vanderbilt University Press; 2006.

3. Hackam DG, Spence JD: Combining multiple approaches for the secondary prevention of vascular events after stroke: a quantitative modeling study. Stroke 2007, 38: |88|-| 885.

4. Chiuve SE, Rexrode KM, Spiegelman D, Logroscino G, Manson JE, Rimm EB: Primary prevention of stroke by healthy lifestyle. Circulation 2008, II 8:947-954.

\section{FlOOOPrime RECOMMENDED}

5. Spence JD: Nutrition in stroke prevention. US Neurology, in press.

6. Keys A: Mediterranean diet and public health: personal reflections. Am J Clin Nutr 1995, 61:132 IS-1323S.

7. de Lorgeril M, Salen P, Martin JL, Mamelle N, Monjaud I, Touboul P, et al.: Effect of a mediterranean type of diet on the rate of cardiovascular complications in patients with coronary artery disease. Insights into the cardioprotective effect of certain nutriments [see comments]. J Am Coll Cardiol 1996, 28: $1103-1108$

\section{FlOOOPrime}

\section{RECOMMENDED}

8. Spence JD: Fasting lipids: the carrot in the snowman. Can J Cardiol 2003, 19:890-892.

9. Spence JD, Jenkins DJ, Davignon J: Dietary cholesterol and egg yolks: not for patients at risk of vascular disease. Can J Cardiol 2010, 26:e336-e339.

10. Estruch R, Ros E, Salas-Salvado J, Covas MI, Pharm D, Corella D, et al.: Primary Prevention of Cardiovascular Disease with a Mediterranean Diet. N Engl J Med 2013.

\section{FlOOOPrime} RECOMMENDED

II. Orlich MJ, Singh PN, Sabate J, Jaceldo-Siegl K, Fan J, Knutsen S, et al.: Vegetarian dietary patterns and mortality in adventist health study 2. JAMA Intern Med 2013, 173:1230-1238.

\section{FlOOOPrime} RECOMMENDED

12. Shai I, Schwarzfuchs D, Henkin Y, Shahar DR, Witkow S, Greenberg I, et al.: Weight loss with a low-carbohydrate, Mediterranean, or low-fat diet. $N$ Engl J Med 2008, 359:229-24l.

\section{FlOOOPrime} RECOMMENDED

13. Spence JD, Jenkins DJ, Davignon J: Egg yolk consumption and carotid plaque. Atherosclerosis 2012, 224(2):469-473.

14. Spence JD, Jenkins DJ, Davignon J: Egg yolk consumption, smoking and carotid plaque: reply to letters to the Editor by Sean Lucan and T Dylan Olver et al. Atherosclerosis 2013, 227:|89-|9|.

15. Catapano AL, Reiner Z, De BG, Graham I, Taskinen MR, Wiklund O, et al.: ESC/EAS Guidelines for the management of dyslipidaemias: the Task Force for the management of dyslipidaemias of the European Society of Cardiology (ESC) and the European Atherosclerosis Society (EAS). Atherosclerosis 2011, 2 I 7(Suppl I):SI-44.

\section{FlOOOPrime
RECOMMENDED}

16. Adult Treatment, Panel III: Third Report of the National Cholesterol Education Program (NCEP) Expert Panel on Detection, Evaluation, and Treatment of High Blood Cholesterol in Adults (Adult Treatment Panel III) final report. Circulation 2002, 106:3143-342I.

\section{FIOOOPrime}

\section{RECOMMENDED}

17. Wang Z, Klipfell E, Bennett BJ, Koeth R, Levison BS, Dugar B, et al:: Gut flora metabolism of phosphatidylcholine promotes cardiovascular disease. Nature 20I I, 472:57-63.

\section{FlOOOPrime}

\section{RECOMMENDED}

18. Tang WHW, Wang Z, Levinson BS, Koeth RA, Britt EB, Fu X, et al: Intestinal Microbiota Metabolism of Phosphatidylcholine and Incident Cardiac Risks. New England Journal of Medicine 2013, 368: $1575-1584$.

19. Wang Z, Klipfell E, Bennett BJ, Koeth R, Levison BS, Dugar B, et al.: Gut flora metabolism of phosphatidylcholine promotes cardiovascular disease. Nature 20II, 472:57-63.

20. $\mathrm{Li}$ Y, Zhou $\mathrm{C}$, Zhou $\mathrm{X}$, Li L: Egg consumption and risk of cardiovascular diseases and diabetes: A meta-analysis. Atherosclerosis 2013.

21. Trichopoulou A, Bamia C, Trichopoulos D: Mediterranean diet and survival among patients with coronary heart disease in Greece. Arch Intern Med 2005, 165:929-935. 
22. Burt A, Thornley $\mathrm{P}$, Illingworth $\mathrm{D}$, White $\mathrm{P}$, Shaw TR, Turner R: Stopping smoking after myocardial infarction. Lancet 1974, I:304-306.

\section{FlOOOPrime}

\section{RECOMMENDED}

23. Garrow JS: Treatment of obesity. Lancet 1992, 340:409-4I3.

24. Reid RD, Mullen KA, Slovinec D'Angelo ME, Aitken DA, Papadakis S, Haley PM, et al.: Smoking cessation for hospitalized smokers: an evaluation of the "Ottawa Model". Nicotine Tob Res 2010, I2:1 I-18. FlOOOPrime RECOMMENDED

25. Spence JD, Barnett HJM: Stroke Prevention, Treatment and Rehabilitation. New York: McGraw-Hill Medical Publishers; 2012.

26. Go AS, Mozaffarian D, Roger VL, Benjamin EJ, Berry JD, Borden WB, et al.: Heart disease and stroke statistics-2013 update: a report from the american heart association. Circulation 2013, 127:e6-e245.

\section{FlOOOPrime \\ RECOMMENDED}

27. Li C, Engström G, Hedblad B, Berglund G, Janzon L: Blood pressure control and risk of stroke: a population-based prospective cohort study. Stroke 2005, 36:725-730.

\section{FlOOOPrime}

28. Hachinski VC, Norris JW: The vascular infrastructure. In The acute stroke. Philadelphia: F.A. Davis; 1985:27-40.

29. Soros P, Whitehead S, Spence JD, Hachinski V: Antihypertensive treatment can prevent stroke and cognitive decline. Nat Rev Neurol 2013, 9:174-178.

30. Spence JD: Cerebral consequences of hypertension. In Hypertension: Pathophysiology, Diagnosis, and Management. Second edition. Edited by Laragh JH, Brenner BM. New York: Raven Press; 1995: 745-753.

31. Spence JD: Antihypertensive drugs and prevention of atherosclerotic stroke. Stroke 1986, 17:808-810.

32. Wong DG, Spence JD, Lamki L, McDonald JWD: Effect of nonsteroidal anti-inflammatory drugs on control of hypertension by beta-blockers and diuretics. Lancet 1986, I(8488):997-I00 I.

33. Howard G, Prineas R, Moy C, Cushman M, Kellum M, Temple E, et al.: Racial and geographic differences in awareness, treatment, and control of hypertension: the REasons for Geographic And Racial Differences in Stroke study. Stroke 2006, 37:1 I7I-1178.

\section{FlOOOPrime}

\section{RECOMMENDED}

34. Spence JD: Individualized therapy for hypertension. Hypertension 2006, 47:ell.

35. Weder $A B$, Gleiberman L, Sachdeva A: Whites excrete a water load more rapidly than blacks. Hypertension 2009, 53:7I5-7|8.

36. Calhoun DA, Jones D, Textor S, Goff DC, Murphy TP, Toto RD, et al:: Resistant hypertension: diagnosis, evaluation, and treatment: a scientific statement from the American Heart Association Professional Education Committee of the Council for High Blood Pressure Research. Circulation 2008, I I7:e510-e526.

\section{FlOOOPrime}

\section{RECOMMENDED}

37. Stowasser M: Update in primary aldosteronism. J Clin Endocrinol Metab 2009, 94:3623-3630.

38. Spence JD: Diagnosis of primary aldosteronism: for medical management, not just surgery. J Hypertens 2009, 27:204-205.

39. de RO, Hackam DG, Spence JD: Effects of Aldosterone on Human Atherosclerosis: Plasma Aldosterone and Progression of Carotid Plaque. Can J Cardiol 2012.
40. Russell RP, Masi AT: The prevalence of adrenal cortical hyperplasia at autopsy and its association with hypertension. Ann Intern Med 1970, 73:195-205.

4I. Kidambi S, Kotchen JM, Grim CE, Raff H, Mao J, Singh RJ, et al.: Association of adrenal steroids with hypertension and the metabolic syndrome in blacks. Hypertension 2007, 49:704-7II.

42. Spence JD: Physiologic tailoring of therapy for resistant hypertension:20 year' experience with stimulated renin profiling. Am J Hypertens 1999, 12:1077-1083.

43. Baker EH, Duggal A, Dong Y, Ireson NJ, Wood M, Markandu ND, et al.: Amiloride, a specific drug for hypertension in black people with T594M variant? Hypertension 2002, 40:13-17.

\section{FlOOOPrime} RECOMMENDED

44. Jones ES, Owen EP, Davidson JS, Van Der Merwe L, Rayner BL: The R563Q mutation of the epithelial sodium channel betasubunit is associated with hypertension. Cardiovasc J Afr 2010 , 21:1-4.

45. Tapolyai M, Uysal A, Dossabhoy NR, Zsom L, Szarvas T, Lengvarszky $Z$, et al.: High prevalence of liddle syndrome phenotype among hypertensive US Veterans in Northwest Louisiana. J Clin Hypertens (Greenwich) 2010, 12:856-860.

46. The Stroke Prevention by Aggressive Reduction in Cholesterol Levels (SPARCL) Investigators: High-Dose Atorvastatin after Stroke or Transient Ischemic Attack. New England Journal of Medicine 2006, 355:549-559.

\section{FlOOOPrime}

47. Sillesen H, Amarenco P, Hennerici MG, Callahan A, Goldstein LB, Zivin J, et al.: Atorvastatin reduces the risk of cardiovascular events in patients with carotid atherosclerosis: a secondary analysis of the Stroke Prevention by Aggressive Reduction in Cholesterol Levels (SPARCL) trial. Stroke 2008, 39:3297-3302.

\section{FlOOOPrime RECOMMENDED}

48. Spence JD, Coates V, Li H, Tamayo A, Munoz C, Hackam DG, et al.: Effects of intensive medical therapy on microemboli and cardiovascular risk in asymptomatic carotid stenosis. Arch Neurol 2010, 67:180-186.

\section{FlOOOPrime}

49. Bader T: The myth of statin-induced hepatotoxicity. Am J Gastroenterol 2010, 105:978-980.

50. Athyros VG, Tziomalos K, Gossios TD, Griva T, Anagnostis P, Kargiotis K, et al:: Safety and efficacy of long-term statin treatment for cardiovascular events in patients with coronary heart disease and abnormal liver tests in the Greek Atorvastatin and Coronary Heart Disease Evaluation (GREACE) Study: a post-hoc analysis. Lancet 2010, 376:1916-1922.

\section{FlOOOPrime} RECOMMENDED

5I. Athyros VG, Mikhailidis DP, Papageorgiou AA, Symeonidis AN, Pehlivanidis AN, Bouloukos VI, et al.: The effect of statins versus untreated dyslipidaemia on renal function in patients with coronary heart disease. A subgroup analysis of the Greek atorvastatin and coronary heart disease evaluation (GREACE) study. J Clin Pathol 2004, 57:728-734.

52. Song $\mathrm{Y}, \mathrm{Nie} \mathrm{H}, \mathrm{Xu} \mathrm{Y}$, Zhang $\mathrm{L}, \mathrm{Wu} \mathrm{Y}$ : Association of statin use with risk of dementia: A meta-analysis of prospective cohort studies. Geriatr Gerontol Int 2013.

53. Spence JD: Statins do not cause intracerebral hemorrhage. Neurology 2012, 79:1076-1077.

54. Golomb BA, Evans MA: Statin adverse effects: a review of the literature and evidence for a mitochondrial mechanism. $\mathrm{Am}$ J Cardiovasc Drugs 2008, 8:373-4I8.

55. Vladutiu GD: Genetic predisposition to statin myopathy. Curr Opin Rheumatol 2008, 20:648-655. 
56. Vladutiu GD, Simmons Z, Isackson PJ, Tarnopolsky M, Peltier WL, Barboi $A C$, et al: Genetic risk factors associated with lipidlowering drug-induced myopathies. Muscle Nerve 2006, 34: I53-162.

57. Spence JD: Polypill: for Polyanna. Int/ J Stroke 2008, 3:92-97.

58. Neuvonen PJ, Jalava KM: Itraconazole drastically increases plasma concentrations of lovastatin and lovastatin acid. Clin Pharmacol Ther 1996, 60:54-61.

59. Neuvonen PJ: Drug interactions with HMG-CoA reductase inhibitors (statins): the importance of CYP enzymes, transporters and pharmacogenetics. Curr Opin Investig Drugs 2010, I I: 323-332.

60. Lilja JJ, Neuvonen M, Neuvonen PJ: Effects of regular consumption of grapefruit juice on the pharmacokinetics of simvastatin. Br J Clin Pharmacol 2004, 58:56-60.

6I. Lilja J], Kivisto KT, Neuvonen PJ: Grapefruit juice-simvastatin interaction: effect on serum concentrations of simvastatin, simvastatin acid, and HMG-CoA reductase inhibitors. Clin Pharmacol Ther 1998, 64:477-483.

62. Dreier JP, Endres M: Statin-associated rhabdomyolysis triggered by grapefruit consumption. Neurology 2004, 62:670.

63. Lilja J], Kivisto KT, Neuvonen PJ: Grapefruit juice increases serum concentrations of atorvastatin and has no effect on pravastatin. Clin Pharmacol Ther 1999, 66:1/8-127.

64. Taylor DW, Barnett HJ, Haynes RB, Ferguson GG, Sackett DL, Thorpe KE, et al.: Low-dose and high-dose acetylsalicylic acid for patients undergoing carotid endarterectomy: a randomised controlled trial. ASA and Carotid Endarterectomy (ACE) Trial Collaborators. Lancet 1999, 353:2179-2184.

65. CAPRIE Steering Committee: A randomised, blinded, trial of clopidogrel versus aspirin in patients at risk of ischaemic events (CAPRIE). Lancet 1996, 348:1329-1339.

66. Sacco RL, Diener HC, Yusuf S, Cotton D, Ounpuu S, Lawton WA, et al.: Aspirin and extended-release dipyridamole versus clopidogrel for recurrent stroke. N EnglJ Med 2008, 359:I238-I25I.

\section{FlOOOPrime}

RECOMMENDED

67. Wong KS, Chen C, Fu J, Chang HM, Suwanwela NC, Huang YN, et al:: Clopidogrel plus aspirin versus aspirin alone for reducing embolisation in patients with acute symptomatic cerebral or carotid artery stenosis (CLAIR study): a randomised, openlabel, blinded-endpoint trial. Lancet Neurol 2010, 9:489-497.

\section{FlOOOPrime
RECOMMENDED}

68. Markus HS, Droste DW, Kaps M, Larrue V, Lees KR, Siebler M, et al.: Dual antiplatelet therapy with clopidogrel and aspirin in symptomatic carotid stenosis evaluated using doppler embolic signal detection: the Clopidogrel and Aspirin for Reduction of Emboli in Symptomatic Carotid Stenosis (CARESS) trial. Circulation 2005, I I I:2233-2240.

\section{FlOOOPrime}

69. Wang Y, Wang Y, Zhao X, Liu L, Wang D, Wang C, et al.: Clopidogrel with aspirin in acute minor stroke or transient ischemic attack. N Engl J Med 2013, 369: I I-19.

\section{FlOOOPrime}

70. Bogiatzi C, Hackam DG, Spence JD: Secular Trends in Ischemic Stroke Subtypes. AHA online abstracts International Stroke Conference. 2013.

71. Caplan LR, Fisher M: The endothelium, platelets, and brain ischemia. Rev Neurol Dis 2007, 4:I|3-I2I.

72. van WC, Hart RG, Connolly S, Austin PC, Mant J, Hobbs FD, et al.: Effect of age on stroke prevention therapy in patients with atrial fibrillation: the atrial fibrillation investigators. Stroke 2009, 40:1410-1416.

FlOOOPrime
RECOMMENDED

73. Connolly SJ, Eikelboom JW, Ng J, Hirsh J, Yusuf S, Pogue J, et al.: Net Clinical Benefit of Adding Clopidogrel to Aspirin Therapy in Patients With Atrial Fibrillation for Whom Vitamin K Antagonists Are Unsuitable. Ann Intern Med 20II, 155:579-586.

74. Spence JD: Stroke: Atrial fibrillation, stroke prevention therapy and aging. Nat Rev Cardiol 2009, 6:448-450.

75. Gladstone DJ, Bui E, Fang J, Laupacis A, Lindsay MP, Tu JV, et al: Potentially preventable strokes in high-risk patients with atrial fibrillation who are not adequately anticoagulated. Stroke 2009, 40:235-240.

76. Schwarz UI, Ritchie MD, Bradford Y, Li C, Dudek SM, FryeAnderson A, et al.: Genetic determinants of response to warfarin during initial anticoagulation. N Engl J Med 2008, 358:999-1008.

77. Spence JD: Atrial fibrillation and stroke prevention: is warfarin still an option? Yes : Debate at the Controversies in Neurology congress, Beijing October 20II.J Neural Transm 2012.

78. Wolf PA, Abbott RD, Kannel WB: Atrial fibrillation as an independent risk factor for stroke: the Framingham Study. Stroke 199|, 22:983-988.

79. Gladstone DJ, Spring M, Dorian P, Thorpe K, Panzov V, Hall J, et al: Prolonged Ambulatory Cardiac Monitoring Improves the Detection and Treatment of Atrial Fibrillation in Patients with Cryptogenic Stroke: Primary Results from the EMBRACE Multicenter Randomized Trial. AHA online abstracts International Stroke Conference. 2013.

80. Poli D, Antonucci E, Cecchi E, Marcucci R, Liotta AA, Cellai AP, et al: Culprit factors for the failure of well-conducted warfarin therapy to prevent ischemic events in patients with atrial fibrillation: the role of homocysteine. Stroke 2005, 36: 2159-2163.

\section{FlOOOPrime}

RECOMMENDED

8I. Spence JD: Mechanisms of thrombogenesis in atrial fibrillation. Lancet 2009, 373:1006.

82. Spence JD: Homocysteine-lowering therapy: a role in stroke prevention? Lancet Neurol 2007, 7:830-838.

83. Spence JD, Stampfer MJ: Understanding the complexity of homocysteine lowering with vitamins: the potential role of subgroup analyses. JAMA 2011, 306:2610-2611.

84. Barnett HJM, Taylor DW, Eliasziw M, Fox AJ, Ferguson GG, Haynes RB, et al.: Benefit of carotid endarterectomy in patients with symptomatic moderate or severe carotid stenosis. N Engl J Med 1998, 339:1415-I425.

85. Rothwell PM, Eliasziw M, Gutnikov SA, Warlow CP, Barnett HJ: Endarterectomy for symptomatic carotid stenosis in relation to clinical subgroups and timing of surgery. Lancet 2004, 363: 915-924.

\section{FlOOOPrime \\ RECOMMENDED}

86. Abbott AL, Adelman MA, Alexandrov AV, Barber PA, Barnett HJ, Beard J, et al.: Why calls for more routine carotid stenting are currently inappropriate: an international, multispecialty, expert review and position statement. Stroke 20/3, 44: $1186-1190$

87. Barnett HJ, Meldrum HE, Eliasziw M: The appropriate use of carotid endarterectomy. CMAJ 2002, 166: I 169-1 I79.

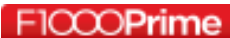

\section{RECOMMENDED}

88. Abbott AL: Medical (nonsurgical) intervention alone is now best for prevention of stroke associated with asymptomatic 
severe carotid stenosis: results of a systematic review and analysis. Stroke 2009, 40:e573-e583.

\section{FlOOOPrime}

89. Marquardt L, Geraghty OC, Mehta Z, Rothwell PM: Low risk of ipsilateral stroke in patients with asymptomatic carotid stenosis on best medical treatment: a prospective, population-based study. Stroke 2010, 41 :ell-el7.

90. Brott TG, Hobson RW, II, Howard G, Roubin GS, Clark WM, Brooks W, et al.: Stenting versus Endarterectomy for Treatment of Carotid-Artery Stenosis. N Engl J Med 2010, 363: I I-23.

\section{FlOOOPrime

RECOMMENDED

91. Wang FW, Esterbrooks D, Kuo YF, Mooss A, Mohiuddin SM, Uretsky BF: Outcomes After Carotid Artery Stenting and Endarterectomy in the Medicare Population. Stroke 2011, 42:2019-2025.

\section{FlOOPrime}

\section{RECOMMENDED}

92. Naylor AR, Gaines PA, Rothwell PM: Who benefits most from intervention for asymptomatic carotid stenosis: patients or professionals? Eur J Vasc Endovasc Surg 2009, 37:625-632.

93. Spence JD: Asymptomatic carotid stenosis. Circulation 2013, I 27:739-742.

94. Spence JD, Pelz D, Veith FJ: Asymptomatic Carotid Stenosis: Identifying Patients at High Enough Risk to Warrant Endarterectomy or Stenting. Stroke $201 \mathrm{I}$.
95. Spence JD, Tamayo A, Lownie SP, Ng WP, Ferguson GG: Absence of microemboli on transcranial Doppler identifies low-risk patients with asymptomatic carotid stenosis. Stroke 2005, 36:2373-2378.

96. Markus HS, King A, Shipley M, Topakian R, Cullinane M, Reihill S, et al.: Asymptomatic embolisation for prediction of stroke in the Asymptomatic Carotid Emboli Study (ACES): a prospective observational study. Lancet Neurol 2010, 9:663-67I.

\section{FlOOOPrime}

RECOMMENDED

97. Spence JD, Hackam DG: Treating Arteries Instead of Risk Factors. A Paradigm Change in Management of Atherosclerosis. Stroke 2010, 41:1193-I199.

98. Spence JD, Eliasziw M, DiCicco M, Hackam DG, Galil R, Lohmann T: Carotid Plaque Area: A Tool for Targeting and Evaluating Vascular Preventive Therapy. Stroke 2002, 33:2916-2922.

99. Sacco RL: Current epidemiology of stroke. In Curr Rev CerebrovasC Dis. Edited by Fisher M, Bogousslavsky J. Philadelphia: Current Medicine; 1993.

100. Wallach L, Nyarai I, Dawson KG: Stimulated renin: a screening test for hypertension. Ann Intern Med 1975, 82:27-34.

I0I. Spence JD: Secondary stroke prevention. Nat Rev Neurol 20I0, 6:477-486.

102. Spence JD: Physiologic tailoring of treatment in resistant hypertension. Curr Cardiol Rev 2010, 6:119-123. 